\title{
PENGARUH MOTIVASI, KOMPETENSI DAN LINGKUNGAN KERJA TERHADAP KINERJA KARYAWAN REKAM MEDIS DI RUMAH SAKIT JIWA Dr. RADJIMAN WEDIODININRAT LAWANG
}

\author{
Silvia Intan Wardani ${ }^{1}$, Wahyu Teja Kusuma ${ }^{2}$, Nindynar Rikatsih ${ }^{3}$ \\ ${ }^{1,2,3}$ Institut Teknologi Sains dan Kesehatan RS dr. Soepraoen \\ (Korespondensi: nindynar@itsk-soepraoen.ac.id )
}

\begin{abstract}
ABSTRAK
Kinerja karyawan rekam medis memiliki peran penting terhadap mutu layanan RSJ Dr. Radjiman Wediodiningrat Lawang. Kinerja karyawan rekam medis dipengaruhi oleh beberapa faktor diantaranya motivasi, kompetensi dan lingkungan kerja. Sehingga perlu diketahui pengaruh motivasi, kompetensi dan lingkungan kerja terhadap kinerja karyawan di RSJ Dr. Radjiman Wediodiningrat Lawang. Pada penelitian ini analisis data menggunakan Regresi Linear diterapkan untuk mengetahui pengaruh motivasi, kompetensi dan lingkungan kerja terhadap kinerja karyawan. Hasil penelitian menunjukan bahwa 78,3\% kinerja karyawan dipengaruhi oleh motivasi, kompetensi dan lingkungan kerja. Sedangkan 21,7\% lainnya dipengaruhi oleh faktor lain. Oleh karena itu, motivasi, kompetensi dan lingkungan kerja merupakan faktor-faktor yang perlu diperhatikan dan memiliki pengaruh yang cukup besar terhadap kinerja karyawan rekam medis RSJ Dr. Radjiman Wediodiningrat Lawang.
\end{abstract}

Kata kunci: karyawan, kompetensi, lingkungan kerja, motivasi, rekam medis.

\begin{abstract}
The performance of medical record employees has an important role in service quality of RSJ Dr. Radjiman Wediodiningrat Lawang. The performance of medical record employees is influenced by several factors including motivation, competence and work environment. So it is necessary to know the influence of motivation, competence and work environment on employee performance in RSJ Dr. Radjiman Wediodiningrat Lawang. In this study, data analysis using Linear Regression was applied to determine the effect of motivation, competence and work environment on employee performance. The results showed that $78.3 \%$ of employee performance was influenced by motivation, competence and work environment. Meanwhile, $21.7 \%$ of employee performance is influenced by other factors. Therefore, motivation, competence and work environment are factors that need to be considered and have a considerable influence on the performance of medical record employees at RSJ Dr. Radjiman Wediodiningrat Lawang.
\end{abstract}

Keywords: employees, competence, work environment, motivation, medical records 
Jurnal Kesehatan Hesti Wira Sakti Vol 8 No 12020

ISSN 2302-4283 (print)

ISSN 2580-9571 (online)

Online di https://jurnal.poltekkes-soepraoen.ac.id DOI: $10.47794 /$ jkhws

PENDAHULUAN

Pelayanan kesehatan suatu rumah sakit merupakan hal yang perlu diperhatikan karena memiliki pengaruh terhadap tingkat kepuasan pasien yang dapat menunjukan seberapa baik mutu pelayanan kesehatan di suatu rumah sakit. Data rekam medis Rumah Sakit Jiwa (RSJ) Radjiman Wediodiningrat Lawang Tahun 2017 dan 2018 menunjukan bahwa nilai parameter Bed Occupacy Rate (BOR) RSJ Radjiman Wediodiningrat Lawang pada tahun 2016 hingga 2017 ialah 54,41\%. BOR merupakan prosentase pemakaian tempat tidur pada satuan waktu tertentu yang memberikan gambaran mengenai tinggi rendahnya tingkat pemanfaatan tempat tidur di rumah sakit dengan nilai parameter ideal 60\% hingga 85\% (Depkes RI, 2005; Kemenkes, 2011). Berdasarkan data BOR RSJ Radjiman Wediodiningrat Lawang Tahun 2017 dan 2018 penggunaan tempat tidur RSJ Radjiman Widiodiningrat Lawang tergolong rendah dibandingkan standar yang ditentukan oleh Departemen Kesehatan RI. Di samping itu, Berdasarkan hasil survei kepuasan pasien yang dilakukan oleh petugas PKRS di ruang rawat inap dengan menggunakan 14 unsur dalam indeks kepuasan masyarakat (IKM) tahun 2018 dengan standard pelayanan minimal (SPM) untuk rawat inap sebesar
90\% didapatkan nilai unsur kecepatan pelayanan sebesar $79 \%$, kenyamanan lingkungan sebesar $75 \%$ dan keamanan pelayanan sebesar 67\%. Survei ini menunjukkan bahwa masih banyak pasien atau keluarga pasien yang tidak puas terhadap pelayanan yang diberikan. Sedangkan dari data pengaduan masyarakat yang didapatkan oleh Tim Pengaduan Masyarakat RSJ Radjiman Wediodiningrat Lawang, terdapat sebanyak 16 pengaduan pada tahun 2017 dan 30 pengaduan pada tahun 2018 dengan kenaikan mendekati 100\%. Hal tersebut menunjukan bahwa mutu pelayanan RSJ Radjiman Wediodiningrat Lawang belum maksimal sehingga terdapat beberapa aspek yang perlu ditingkatkan.

Salah satu aspek yang sangat berpengaruh terhadap mutu layanan rumah sakit adalah karyawan di rumah sakit tersebut (Juliani, 2017). Menurut data dari Departemen Kesehatan R1 Tahun 2015, karyawan rumah sakit merupakan tenaga terbanyak dan memberikan $40 \%$ layanan terhadap pasien. Salah satu bagian karyawan yang melakukan pelayanan 24 jam adalah karyawan rekam medis. Sebagian besar unit layanan di rumah sakit memerlukan tenaga karyawan rekam medis untuk memberikan pelayanan kepada masyarakat. Pelayanan rawat inap, rawat jalan, unit-unit khusus 
ISSN 2302-4283 (print)

ISSN 2580-9571 (online)

Online di https://jurnal.poltekkes-soepraoen.ac.id

DOI: $10.47794 / \mathrm{jkhws}$

memerlukan tenaga karyawan rekam medis

sesuai spesifikasinya. Dengan demikian

SDM karyawan rekam medis adalah SDM

yang sangat menentukan kualitas dan mutu

pelayanan di rumah sakit. Besarnya

proporsi tersebut memiliki potensi untuk

kiat-kiat pengembangan manajemen mutu pelayanan kesehatan (Hasanbasri, 2017).

Mengingat perlunya peningkatan layanan kesehatan di RSJ Radjiman Wediodiningrat

Lawang dan pentingnya kinerja karyawan rekam medis dalam memberikan layanan kesehatan, maka perlu dilakukan peningkatan kinerja karyawan rekam medis di RSJ Radjiman Wediodiningrat Lawang. Permasalahan mengenai kinerja karyawan merupakan permasalahan yang akan selalu dihadapi oleh pihak manajemen perusahaan termasuk rumah sakit. Kinerja atau performance merupakan hasil kerja atau prestasi kerja yang pada kenyataannya kinerja mempunyai makna yang lebih luas. Kinerja bukan hanya sebagai hasil dari suatu pekerjaan tetapi juga termasuk bagaimana proses pekerjaan berlangsung. Kinerja merupakan hasil pekerjaan yang mempunyai hubungan kuat dengan tujuan strategis organisasi, kepuasaan konsumen, serta berpengaruh terhadap kontribusi pada ekonomi. Kinerja adalah tentang apa yang dikerjakan dan bagaimana cara mengerjakannya (Wibowo, 2015).
Berdasarkan studi pendahuluan yang dilakukan peneliti pada tanggal 3 dan 4 Januari 2019 di RSJ Radjiman Wediodiningrat Lawang menggunakan teknik wawancara dapat diketahui bahwa sebagian besar karyawan yang bertugas hanya bekerja berdasarkan orientasi tugas tanpa memiliki motivasi yang jelas. Motivasi kerja merupakan suatu keadaan yang mempengaruhi seseorang untuk terus meningkatkan, mengarahkan serta memelihara prilakunya yang berhubungan secara langsung maupun tidak langsung dengan lingkungan kerjanya (Riyadi dan Kusnanto, 2015). Selain itu, karyawan di RSJ Radjiman Wediodiningrat Lawang memiliki kompetensi yang bervariasi. Menurut Hasibuan (2016) kompetensi merupakan salah satu faktor yang dapat mempengaruhi kinerja karyawan. Dengan demikian kompetensi memiliki peranan yang amat penting dalam pelaksanaan kerja karyawan rekam medis di rumah sakit. Kompetensi yang sesuai dapat membantu tenaga rekam medis dalam menyelasaikan beban tugas yang harus dilakukan. Namun apabila pekerjaan yang dilakukan di luar kompetensinya atau kompetensinya tidak memadai maka akan terjadi yang sebaliknya. Kompetensi merupakan sesuatu yang dapat digunakan untuk memprediksi tingkat kinerja karyawan. Di 
Online di https://jurnal.poltekkes-soepraoen.ac.id DOI: $10.47794 / \mathrm{jkhws}$

sisi lain, menurut bagian pelayanan dan kepala ruangan, keadaan sarana dan prasarana yang dibutuhkan di ruang karyawan sebagian besar masih sangat kurang sehingga menghambat karyawan dalam melaksanakan tugas. Sebagian besar karyawan mengatakan bahwa kondisi lingkungan kerja kurang bersih, keadaan fisik bangunan sudah tua dan kurangnya jumlah karyawan. Permasalahan ini menurut beberapa karyawan dan kepala ruangan mengatakan sudah pernah disampaikan kepada manajemen rumah sakit, namun penyelesaiannya masih dirasakan kurang optimal. Meskipun demikian, mereka juga menambahkan bahwa tetap berusaha bekerja secara optimal mengingat tanggung jawab terhadap profesi dan pasien.

Berdasarkan fenomena yang telah diuraikan dan besarnya pengaruh sumber daya manusia (SDM) karyawan terhadap mutu pelayanan di rumah sakit maka pengaruh motivasi, kompetensi dan lingkungan kerja terhadap kinerja karyawan rekam medis di RSJ Radjiman Lawang penting untuk diketahui. Tujuan Penelitian ini adalah untuk menganalisis tingkat pengaruh motivasi, kompetensi dan lingkungan kerja terhadap kinerja karyawan rekam medis di RSJ Radjiman Wediodiningrat Lawang.
Metode yang digunakan pada penelitian ini adalah Regresi Linear Berganda atau bisa disebut Multiple Linear Regression (MLR). MLR merupakan pengembangan dari Regresi Linear sederhana dimana terdapat lebih dari satu variabel independen (Wisudaningsi, Arofah dan Belang, 2019). Regresi Linear Berganda pada penelitian ini diterapkan untuk mengetahui pengaruh tiga variabel bebas yang terdiri motivasi, kompetensi dan lingkungan kerja terhadap variabel terikat berupa kinerja karyawan. Penelitian ini dilakukan untuk mengetahui seberapa besar pengaruh motivasi, kompetensi dan lingkungan kerja terhadap kinerja karyawan agar dapat digunakan dalam peningkatan mutu pelayanan RSJ Radjiman Wediodiningrat Lawang.

\section{METODE PENELITIAN}

Desain yang digunakan pada penelitian ini adalah analitik kuantitatif yang diawali dengan (i) studi literatur (ii) pengumpulan data (iii) penerapan MLR (iv) uji statistik (v) analisa hasil (vi) penarikan kesimpulan. Studi literatur dilakukan untuk mendapatkan data sekunder yang bersumber dari Kementerian Kesehatan RI. Selanjutnya dilakukan pengumpulan data primer berupa wawancara langsung kepada karyawan di RSJ Radjiman Wediodiningrat Lawang pada bulan Januari 2019 yang 
Jurnal Kesehatan Hesti Wira Sakti Vol 8 No 12020

ISSN 2302-4283 (print)

ISSN 2580-9571 (online)

Online di https://jurnal.poltekkes-soepraoen.ac.id

DOI: $10.47794 /$ jkhws

dilakukan menggunakan teknik Radom

Sampling dengan jumlah sampel 102 orang

karyawan. Teknik Analisis Data yang

digunakan adalah MLR untuk mengetahui

pengaruh antara variabel bebas berupa

motivasi, kompetensi dan lingkungan kerja

dengan variabel terikat berupa kinerja

karyawan rekam medis RSJ Radjiman

Wediodiningrat Lawang dan analisis

statistik dengan bantuan program SPSS.

\section{HASIL PENELITIAN}

Data hasil penelitian mengenai karakteristik responden yang meliputi pendidikan, masa kerja, motivasi, kompetensi, lingkungan kerja dan kinerja ditunjukan pada Tabel 1.

Tabel 1. Karakteristik Responden

\begin{tabular}{llcc}
\hline No & \multicolumn{1}{c}{ Karakteristik } & $\boldsymbol{\Sigma N}$ & \multicolumn{1}{c}{$\boldsymbol{\Sigma} \%$} \\
\hline 1 & Pendidikan & & \\
& SMK & 11 & 10,78 \\
& DIII & 75 & 73,53 \\
& Sarjana & 16 & 15,69 \\
\hline 2 & Masa kerja (tahun) & & \\
& $1-5$ & 53 & 51,96 \\
& 6-10 & 37 & 36,27 \\
& $10-15$ & 12 & 11,77 \\
\hline 3 & Motivasi & & \\
& Baik & 59 & 48,19 \\
& Cukup & 38 & 45,78 \\
& Kurang & 5 & 5,02 \\
\hline 4 & Kompetensi & & \\
& Baik & 51 & 53,01 \\
& Cukup & 48 & 43,37 \\
& Kurang & 3 & 3,22 \\
\hline 5 & Lingkungan kerja & & \\
& Baik & 56 & 51,80 \\
& Cukup & 36 & 36,14 \\
& Kurang & 10 & 12,04 \\
\hline
\end{tabular}

Data pada Tabel 1 selanjutnya dianalisa dengan terlebih dahulu melakukan uji normalitas data, uji korelasi, dan penerapan Regresi Linear Berganda.

\section{a. Uji Normalitas Data}

Uji normalitas data dilakukan untuk mengetahui apakah data yang digunakan berdistribusi normal atau sebaliknya. Uji normalitas data dilakukan menggunakan metode Kolmogorov-Smirnov dengan bantuan SPSS dimana distribusi data dinyatakan normal apabila nilai signifikansi lebih dari 0,05 dan tidak normal apabila nilai kurang dari 0,05.

\section{b. Uji Korelasi}

Hasil uji korelasi yang dilakukan menggunakan teknik korelasi Pearson Product Moment (PPM) menunjukan bahwa terdapat nilai koefisien sebesar 0,495 pada hubungan antara motivasi dan kinerja. Hal ini menunjukan bahwa terdapat pengaruh motivasi terhadap kinerja dengan tingkat sedang.

Pada uji korelasi yang dilakukan selanjutnya dapat diketahui bahwa korelasi antara kompetensi dan kinerja mendapatkan nilai koefisien sebesar 
Jurnal Kesehatan Hesti Wira Sakti Vol 8 No 12020

ISSN 2302-4283 (print)

ISSN 2580-9571 (online)

Online di https://jurnal.poltekkes-soepraoen.ac.id

DOI: $10.47794 / \mathrm{jkhws}$

0,8 yang berarti bahwa kompetensi memiliki tingkat pengaruh yang sangat kuat terhadap kinerja.

Korelasi antara lingkungan kerja dengan kinerja memiliki nilai koefisiennya sebesar 0,646 . Hal ini menunjukan bahwa terdapat tingkat pengaruh yang kuat antara lingkungan kerja terhadap kinerja.

Ketiga variabel bebas dan variabel terikat memiliki arah hubungan positif yang menunjukan bahwa kinerja meningkat seiring meningkatnya motivasi, kompetensi dan lingkungan kerja.

\section{c. Penerapan Regresi Linear Berganda}

Hasil pada Output Model Summary yang diperoleh dari uji Regresi Linier Berganda menunjukkan nilai $\mathrm{R}$ sebesar 0,891 . Nilai $R$ yang mendekati nilai 1 menunjukan bahwa terdapat hubungan yang erat antara variabel independen terhadap variabel dependen. Sedangkan nilai Adjusted $R$ Square sebesar 0,783 menjadi dasar bahwa terdapat pengaruh antara motivasi, kompetensi dan lingkungan kerja terhadap kinerja karyawan sebesar $78,3 \%$. Sedangkan $21,7 \%$ sisanya dipengaruhi oleh variabel lain di luar batasan penelitian ini.

Tingkat signifikansi yang diperoleh ialah sebesar 0,000 sehingga dapat disimpulkan bahwa motivasi, kompetensi dan lingkungan kerja secara bersama-sama berpengaruh terhadap kinerja karyawan di RSJ Radjiman Wediodiningrat Lawang. Nilai signifikansi berdasarkan uji-t yang dilakukan untuk masing-masing variabel menunjukan nilai motivasi sebesar 0,023, kompetensi sebesar 0,000 dan lingkungan kerja sebesar 0,000 yang memiliki arti bahwa semua varabel tersebut memiliki $\mathrm{p}<0,05$. Sehingga dapat disimpulkan bahwa masing-masing varibel yaitu motivasi, kompetensi dan lingkungan kerja berpengaruh signifikan secara parsial terhadap kinerja karyawan rekam medis di RSJ Radjiman Wediodiningrat Lawang.

Persamaan Regresi Berganda yang digunakan terdapat pada Persamaan 1.

$$
\mathrm{y}=\mathrm{a}_{0}+\mathrm{a}_{1} \mathrm{x}_{1}+\mathrm{a}_{2} \mathrm{X}_{2}+\mathrm{a}_{3} \mathrm{X}_{3}
$$

Variabel y merepresentasikan kinerja karyawan, $\mathrm{x}_{1}$ merupakan motivasi, $\mathrm{x}_{2}$ merupakan kompetensi dan $\mathrm{x}_{3}$ adalah lingkungan kerja.

\section{PEMBAHASAN}


Jurnal Kesehatan Hesti Wira Sakti Vol 8 No 12020

ISSN 2302-4283 (print)

ISSN 2580-9571 (online)

Online di https://jurnal.poltekkes-soepraoen.ac.id

DOI: $10.47794 /$ jkhws

Pembahasan pada penelitian ini terdiri dari

(i) pengaruh motivasi terhadap kinerja

karyawan rekam medis di RSJ Radjiman

Wediodiningrat Lawang (ii) pengaruh

kompetensi terhadap kinerja karyawan

rekam medis di RSJ Radjiman

Wediodiningrat Lawang (iii) pengaruh

lingkungan kerja terhadap kinerja

karyawan rekam medis di RSJ Radjiman

Wediodiningrat Lawang (iv) pengaruh

motivasi, kompetensi dan lingkunan kerja

secara bersama-sama terhadap kinerja

karyawan rekam medis di RSJ Radjiman

Wediodiningrat Lawang.

a. Pengaruh motivasi terhadap kinerja karyawan rekam medis di RSJ Radjiman Wediodiningrat Lawang

Berdasarkarkan Tabel 1, dari 102 responden terdapat 59 orang $(48,19 \%)$ dengan kategori motivasi baik dan kategori motivasi kurang sebanyak 5 orang (5,02\%). Berdasarkan level Pendidikan, terdapat 45 orang karyawan dengan pendidikan terakhir DIII yang memiliki motivasi dengan kategori baik $(45,7 \%)$ dan kategori kurang sebanyak 3 orang (2,8\%). Berdasarkan masa kerja 1-5 tahun kategori motivasi baik dimiliki sebanyak 46 orang $(45,6 \%)$ dan kategori motivasi kurang menurut masa kerja 1-5 tahun dan masa kerja 6-

10 tahun sebanyak 1 orang $(0,9 \%)$. Motivasi adalah dorongan yang timbul dari penilaian rekam medis terhadap organisasi dalam pemenuhan kebutuhan. Indikator yang diukur dalam variabel motivasi ini adalah motivasi afiliasi, reward dan punishment. Hipotesis pertama menyatakan ada pengaruh positif dan signifikan motivasi terhadap kinerja karyawan rekam medis di RSJ Radjiman Lawang. Hasil analisis data secara statistik menunjukkan hasil uji n (uji koefisien regresi secara parsial) dengan nilai $\mathrm{n}$ hitung 9,710 dan nilai signifikansi 0,023. Berdasarkan data tersebut maka dapat disimpulkan bahwa motivasi berpengaruh signifikan secara parsial terhadap kinerja karyawan rekam medis di RSJ Radjiman Wediodiningrat Lawang. Hal ini menunjukkan bahwa semakin baik motivasi karyawan semakin baik pula kinerjanya.

Penelitian sebelumnya dilakukan oleh Pujiastuti (2019) dengan hasil penelitian yang menunjukan bahwa motivasi berpengaruh signifikan terhadap kinerja pegawai pada RSUD dr. Moewardi Surakarta $(\mathrm{t}=13,482 ; \mathrm{p}$ $=0,000)$. Penelitian lainnya dilakukan oleh Riyanti dan Sudibya (2013) yang 
Online di https://jurnal.poltekkes-soepraoen.ac.id

DOI: $10.47794 / \mathrm{jkhws}$

mendapatkan hasil bahwa motivasi berpengaruh signifikan terhadap kinerja karyawan RSU Dharma Usadha Bali $(\mathrm{t}=9,352 ; \mathrm{p}=0,000)$. Penelitian lain juga dilakukan oleh Mudayana (2015) yang mendmenunjukan bahwa motivasi berpengaruh signifikan terhadap kinerja karyawan di RS. Nur Hidayat Bantul $(\mathrm{p}=0,000)$. Selain itu, Setyaningsih dan Hartanto (2013) melakukan penelitian dengan hasil motivasi berpengaruh secara signifikan terhadap kinerja pegawai di Kecamatan Jumanto Kabupaten Karanganyar $(t=2,150 ; p=0,041)$. Sedangkan penelitian yang dilakukan oleh Kartono dan Sriwidodo (2016) menunjukan bahwa pada motivasi dan kinerja guru SMP swasta di Kecamatan Tegowanu Kabupaten Grobogan terdapat pengaruh yang signifikan $(\mathrm{p}=$ $0,011)$.

\section{b. Pengaruh kompetensi terhadap} kinerja karyawan rekam medis di

\section{RSJ Radjiman Wediodiningrat}

\section{Lawang}

Berdasarkan Tabel 1 diketahui bahwa sebanyak 51 orang $(53,01 \%)$ memiliki kompetensi dengan kategori baik dan sebanyak 3 orang $(3,22 \%)$ memiliki potensi dengan kategori kurang.
Terdapat pengaruh yang baik antara kompetensi terhadap kinerja karyawan dengan masa kerja 1-5 tahun dengan jumlah 46 orang $(45,6 \%)$. Sedangkan kategori kurang sebanyak 1 orang $(0,9 \%)$.

Kompetensi merupakan kemampuan intelektual, fisik dan hubungan antar manusia yang mendasari karyawan dalam melaksanakan asuhan keperawatan. Indikator yang diukur dalam kompetensi adalah intelektual, fisik dan human relation. Hipotesis kedua menyatakan terdapat pengaruh positif dan signifikan pada kompetensi terhadap kinerja karyawan di RSJ Radjiman Wediodiningrat Lawang. Hasil uji $\mathrm{n}$ untuk varabel kompetensi menunjukkan nilai $\mathrm{n}$ hitung sebesar 5,894 dengan nilai signifikansi 0,000 . Berdasarkan data tersebut dapat disimpulkan bahwa kompetensi berpengaruh signifikan secara parsial terhadap kinerja karyawan di RSJ radjiman Lawang. Kinerja karyawan semakin baik seiring meningkatnya kompetensi.

Hasil penelitian ini juga sesuai dengan penelitian yang dilakukan oleh Riyanti dan Sudibya (2013) yang mendapatkan hasil berupa adanya pengaruh signifikan kompetensi terhadap kinerja 
Jurnal Kesehatan Hesti Wira Sakti Vol 8 No 12020

ISSN 2302-4283 (print)

ISSN 2580-9571 (online)

Online di https://jurnal.poltekkes-soepraoen.ac.id

DOI: $10.47794 / \mathrm{jkhws}$

karyawan pada RS. Dharma Usadha

Bali ( $\mathrm{t}=6,315 ; \mathrm{p}=0,000)$. Penelitian

lain dilakukan oleh Siwantara (2017)

yang menemukan adanya pengaruh

positif dan signifikan antara

kompetensi profesional dengan kinerja

dosen Politeknik Negeri Malang yang

ditunjukkan oleh nilai standardized

regression weight sebesar 0,21.

Sedangkan Ardiana dan Brahmayanti

(2015) melibatkan kompetensi dalam

penelitannya yang terdiri dari

pengetahuan, ketrampilan dan

kemampuan. Hasil penelitian tersebut menunjukan bahwa pengetahuan tidak berpengaruh signifikan terhadap kinerja namun ketrampilan dan kemampuan SDM UKM berpengaruh secara signifikan terhadap kinerja UKM di Surabaya. Perbedaan hasil terdapat pada variabel kompetensi khususnya pengetahuan karena terdapat perbedaan indikator pada masing-masing variabel. Namun secara umum seluruh variabel yang terdiri dari pengetahuan, ketrampilan dan kemampuan secara bersama sama berpengaruh terhadap kinerja UKM di Surabaya.

\section{c. Pengaruh lingkungan kerja terhadap kinerja karyawan rekam}

\section{medis di RSJ Radjiman Wediodiningrat Lawang}

Kategori baik antara lingkungan kerja terhadap kinerja dimiliki oleh sebanyak 56 orang $(51,80 \%)$ dan kategori kurang oleh sebanyak 10 orang $(12,04 \%)$. Berdasarkan usia, sebanyak 47 orang $(46,6 \%)$ dengan usia 20-35 tahun mendapatkan kategori baik dan 1 orang $(0,9 \%)$ dengan kategori kurang. Berdasarkan masa kerja 1-5 tahun pengaruh yang baik antara lingkungan kerja terhadap kinerja karyawan dengan kategori baik ialah sebanyak 46 orang $(45,6 \%)$ dan kategori kurang sebanyak 1 orang (0,9\%). Lingkungan kerja adalah kondisi lingkungan fisik dan non fisik tempat karyawan melaksanakan tugas pokok dan fungsinya. Indikator yang diukur dalam hal ini adalah hubungan dengan teman sejawat, hubungan dengan pimpinan, sarana dan prasarana serta kebersihan lingkungan. Hipotesis ketiga menyatakan adanya pengaruh signifikan lingkungan kerja terhadap kinerja karyawan di Rumah Sakit Brawijaya Lawang, Malang. Hasil uji analisis $\mathrm{n}=5,237$ dan signifikansi $=$ 0,000. Berdasarkan data tersebut maka dapat disimpulkan bahwa lingkungan kerja berpengaruh secara parsial 
Online di https://jurnal.poltekkes-soepraoen.ac.id

DOI: $10.47794 /$ jkhws

terhadap kinerja perawat di Rumah

Sakit Brawijaya Lawang, Malang.

masing penelitian mempunyai profesi yang berbeda.

Semakin baik serta kondusif lingkungan kerja karyawan maka kinerja juga akan semakin baik.

Hasil penelitian ini sesuai dengan penelitian yang dilakukan oleh Cahyani dan Ardana (2016) dengan hasil lingkungan kerja fisik yang berpengaruh signifikan terhadap kinerja pegawai non medis pada RS Melati Husada Malang $\mathrm{t}=2,595 ; \mathrm{p}=$ 0,014). Sedangkan penelitian Setyaningsih dan Hartanto (2013) dengan hasil lingkungan kerja berpengaruh secara signifikan terhadap kinerja pegawai di Kecamatan Jumanto Kabupaten Karanganyar, Malang yang dibuktikan dengan hasil uji $\mathrm{n}$ hitung sebesar 3,040 dengan $\mathrm{p}$ value sebesar 0,05 . Sedangkan dari penelitian yang dilakukan oleh Kartono dan Sriwidodo (2016) diperoleh hasil yang menunjukan bahwa lingkungan kerja memiliki pengaruh yang signifikan terhadap kinerja guru SMP swasta di Kecamatan Tegowanu Kabupaten Grobogan. Dari hasil uji n didapatkan signifikansi sebesar 0,002. Hal ini membuktikan bahwa lingkungan kerja sangat berpengaruh terhadap kinerja walaupun responden pada masing-

d. Pengaruh motivasi, kompetensi dan lingkungan kerja secara bersamasama terhadap kinerja karyawan rekam medis di RSJ Radjiman Wediodiningrat Lawang

Hipotesis keempat menyatakan adanya pengaruh signifikan antara motivasi, kompetensi dan lingkungan kerja secara bersama-sama terhadap kinerja karyawan rekam medis di RSJ Radjiman Wediodiningrat Lawang.

Hasil uji regresi linear berganda yang dilakukan menunjukkan nilai $\mathrm{n}$ hitung sebesar 67,120 dengan nilai signifikansi 0,000 dimana nilai tersebut kurang dari 0,05. Jadi dapat disimpulkan bahwa motivasi, kompetensi dan lingkungan kerja secara bersama-sama memiliki pengaruh yang signifikan terhadap kinerja karyawan.

Persamaan regresi yang digunakan mengacu pada Persamaan 1 diterapkan pada persamaan 2 .

$y=1,721+0,518 x_{1}+1,072 x_{2}+0,137 x_{3}$

Dari persamaan regresi tersebut dapat diketahui bahwa $\mathrm{x}_{2}$ yang merupakan variabel kompetensi memiliki 
Online di https://jurnal.poltekkes-soepraoen.ac.id

DOI: $10.47794 /$ jkhws

koefisien regresi paling besar dibandingkan variabel lainnya yaitu 1,072. Sehingga dapat disimpulkan varibel yang paling dominan mempengaruhi kinerja adalah kompetensi.

Nilai konstanta yang didapatkan adalah 1,721 yang menunjukan bahwa jika motivasi, kompetensi dan lingkungan kerja bernilai 0 maka kinerja karyawan adalah sebesar 1,721 dan bila variabel motivasi meningkat satu satuan maka akan meningkatkan kinerja sebesar 0,518 dengan asumsi variabel lain bernilai tetap. Peningkatan satu satuan pada varabel kompetensi akan meningkatkan kinerja sebesar 1,072 dengan asumsi variabel yang lain bernilai tetap dan peningkatan satu satuan pada variabel lingkungan kerja akan meningkatkan kinerja sebesar 0,137 dengan asumsi variabel lain juga bernilai tetap.

Sedangkan nilai Adjusted $R$ Square 0,783 memiliki arti bahwa variabel motivasi, kompetensi dan lingkungan kerja mempengaruhi kinerja karyawan rekam medis sebesar 78,3\% sedangkan sisanya $21,7 \%$ dipengaruhi oleh variabel lainnya yang tidak termasuk dalam penelitian ini.

\section{KESIMPULAN}

Motivasi berpengaruh signifikan terhadap kinerja karyawan di RSJ Radjiman Wediodiningrat Lawang $(\mathrm{n}=9,710 ; \mathrm{p}=$ 0,023). Hasil ini menunjukkan semakin baik motivasi karyawan di RSJ Radjiman Lawang maka akan semakin baik pula kinerjanya dan demikian sebaliknya.

Kompetensi berpengaruh signifikan terhadap kinerja karyawan di RSJ Radjiman Wediodiningrat Lawang ( $\mathrm{n}=$ 5,894; $\mathrm{p}=0,000)$. Hasil ini menunjukkan semakin baik kompetensi karyawan di RSJ Radjiman Wediodiningrat Lawang maka akan semakin baik pula kinerjanya demikian pula sebaliknya.

Lingkungan Kerja berpengaruh signifikan terhadap kinerja Karyawan di RSJ Radjiman Wediodiningrat Lawang ( $\mathrm{n}=$ 5,237; $\mathrm{p}=0,000)$. Hasil ini menunjukkan semakin baik lingkungan kerja karyawan di RSJ Radjiman Wediodiningrat Lawang maka akan semakin baik pula kinerjanya dan berlaku sebaliknya

Motivasi, kompetensi dan lingungan kerja secara bersama-sama berpengaruh signifikan terhadap kinerja karyawan di RSJ Radjiman Lawang ( $\mathrm{n}=67,120 ; \mathrm{p}=$ 0,000). Sedangkan variabel kompetensi mempunyai pengaruh yang paling dominan dibandingkan dengan variabel lainnya. 
ISSN 2302-4283 (print)

ISSN 2580-9571 (online)

Online di https://jurnal.poltekkes-soepraoen.ac.id

DOI: $10.47794 /$ jkhws

Peningkatan kompetensi karyawan dapat

dilakukan dengan memberi kesempatan

untuk meningkatkan pendidikan,

melakukan pelatihan-pelatihan sesuai

kebutuhan, mengikuti seminar dan lain

sebagainya karena peningkatan kompetensi

akan meningkatkan kinerja karyawan yang

dapat memicu peningkatan mutu pelayanan

rumah sakit secara umum.

\section{DAFTAR PUSTAKA}

Ardiana I. D. K. R., I. A. Brahmayanti dan Subaedi. 2015. Kompetensi SDM UKM dan Pengaruhnya Terhadap Kinerja UKM di Surabaya. Jurnal Manajemen dan Kewirausahaan 12(1): 42-55.

Arwani, S. 2015. Manajemen Bangsal Keperawatan. Jakarta: EGC.

Cahyani, P. N. dan I. K. Ardana. 2016. Pengaruh Lingkungan Kerja Fisik, Gaya Kepemimpinan dan Insentif Finansial Terhadap Kinerja Pegawai Non Medis Pada RS. Balimed Denpasar. Jurnal Manajemen Universitas Udayana 2(6) : 423-435.

Departemen Kesehatan RI. 2015. Standar Tenaga Keperawatan Di Rumah Sakit. Jakarta: Depkes RI.

Gunawa. 2016. Hubungan Antara Beban Kerja Dengan Kepuasan Kerja Perawat Di Unit Rawat Inap Badan Rumah Sakit Tabanan 2010. Skripsi: UNUD

Gurucci dan Apriani. 2011. Kinerja Tenaga Karyawan Di Unit Rawat Inap Rumah Sakit Kepolisian Pusat
Raden Said Sukanto Tahun 2004. Jurnal Kedokteran dan Kesehatan, 2 (1): $1-10$

Griffin. 2016. Manajemen, Edisi 7. Jakarta: Erlangga.

Hasibuan, M. 2016. Manajemen Sumber Daya Manusia, Edisi Revisi Jakarta: Bumi Aksara.

Hendrarni, W. 2017. Pengaruh Motivasi Kerja Terhadap Kinerja Asuhan Keperawatan Dalam Pengkajian Dan Implementasi Perawat Pelaksana Di Rumah Sakit Bhayangkara Medan Tahun 2008. Skripsi: Universitas Sumatera Utara.

Hidayat, A.A.A. 2015 Metode Penelitian Karyawan Dan Teknik Analisis Data. Jakarta: Salemba Medika.

Ilyas. 2016. Kinerja, Teori, Penilaian Dan Penelitian. Jakarta: Pusat Kajian Ekonomi Masyarakat FKM UI.

Juliani. 2017. Pengaruh Motivasi Intrinsik Terhadap Kinerja Karyawan Pelaksana Di Instalasi Rawat Inap RSU Dr. Pirngadi Medan Tahun 2007. Universitas Sumatera Utara

Kartono \& Sriwidodo. 2016. Pengaruh Motivasi Kerja, Lingkungan Kerja Dan Kesejahteraan Terhadap Kinerja Guru SMP Swasta.Jurnal Manajemen Sumber Daya Manusia, 3(2): $89-89$

Kuntoro, A. 2015. Buku Ajar Manajemen Karyawan Yogyakarta: Nuha Medika

Mangkuprawira. 2014. Manajemen Sumber Daya Manusia Strategik. Jakarta: Graha Indonesia. 
ISSN 2302-4283 (print)

ISSN 2580-9571 (online)

Online di https://jurnal.poltekkes-soepraoen.ac.id

DOI: $10.47794 / \mathrm{jkhws}$

Mastika, N. IGP. 2015. Pengaruh komunikasi, sikap pimpinan, lingkungan kerja dan kompensasi terhadap semangat kerja pegawai kantor camat di kabupaten buleleng. Tesis, UNUD.

Mayawati, D. 2017. Hubungan Antara Motivasi Dengan Kepuasan Kerja Karyawan Di Puskesmas Rawat Inap Kabupaten Klaten. Skripsi: Universitas Muhammadiyah.

Muchlas, M. 2015. Perilaku Organisasi. Yogyakarta: Gadjah Mada University Press.

Mudayana, A. 2015. Pengaruh Motivasi Dan Beban Kerja Terhadap Kinerja Karyawan Di RS. Nur Hidayat Bantul. Jurnal Kes-Mas. 4(2): 74143.

Muninjaya, G. 2014. Manajemen Kesehatan. Edisi 2. Jakarta: EGC.

Nursalam. 2017. Manajemen Keperawatan Aplikasi dalam Praktik Keperawatan Profesional. Edisi kedua. Jakarta: Salemba Medika.

Nursalam. 2015. Konsep dan Penerapan Metodologi Penelitian Ilmu Keperawatan: Pedoman Skripsi, Tesis, dan Instrumen Penelitian Keperawatan. Jakarta: Salemba Medika.

Pujiastuti, D. 2019. Pengaruh Kepemimpinan, Motivasi, Komunikasi, Disiplin Dan Pendidikan Terhadap Kinerja Pegawai Pada RSUD dr. Moewardi Surakarta. Jurnal Excellent, 1(1): 120.

Riyanti, G. A. R. dan I. G. A. Sudibya. 2013. Pengaruh Motivasi Dan
Kompetensi Terhadap Kinerja

Karyawan Pada RSU Dharma

Usadha. Jurnal Manajemen

Universitas Udayana, 2(6): 610624.

Sedarmayanti. 2014. Manajemen Sumber Daya Manusia dan Produksi Kerja. Bandung: Mandar Maju.

Sulistiyani A. T. dan Rosidah. 2014. Manajemen Sumber Daya Manusia, Konsep, Teori dan Pengembangan dalam Konteks Organisasi Publik. Yogyakarta: Graha Rahayu.

Sunyoto, D. 2016. Manajemen Sumber Daya Manusia. Yogyakarta: KAPS

Sumarni, M. 2016. Pengantar Bisnis (Dasar-dasar Ekonomi Perusahan). Yogyakarta: Liberty.

Sutrisno, 2015, Manajaemen Sumber Daya Manusia, Cetakan ketiga, Prenada Media Group Jakarta

Siregar, M. 2015. Pengaruh Motivasi Terhadap Kinerja karyawan Pelaksana Di Ruang Rawat Inap Rumah Sakit Umum Daerah Swadana Tarutung Tapanuli Utara Tahun 2008. Universitas Sumatera Utara.

Siwantara, W. 2017. Pengaruh Kompetensi Profesional Dan Motivasi Kerja Serta Iklim Organisasi Terhadap Disiplin Kerja Dan Kinerja Dosen Politeknik Bali. Tesis, UNUD

Swansburg, R. C. 2016. Pengantar Kepemimpinan Dan Manajemen Keperawatan Untuk Perawat Klinis. Jakarta: EGC.

Setyaningsih dan Hartanto, A. 2013. Pengaruh Kepemimpinan, Motivasi, Komunikasi Dan 
Jurnal Kesehatan Hesti Wira Sakti Vol 8 No 12020

ISSN 2302-4283 (print)

ISSN 2580-9571 (online)

Online di https://jurnal.poltekkes-soepraoen.ac.id

DOI: $10.47794 / \mathrm{jkhws}$

$$
\begin{array}{lr}
\text { Lingkungan Kerja } & \begin{array}{r}
\text { Terhadap } \\
\text { Kinerja Pegawai }
\end{array} \\
\text { Kecamatan } \\
\text { Jumantono } & \text { Kabupaten } \\
\text { Karanganyar. Jurnal } & \text { Manajemen } \\
\text { Sumber Daya Manusia, 4(1): 58-67. }
\end{array}
$$

Sutrisno, E .2013, Manajaemen Sumber Daya Manusia, Cetakan ketiga. Jakarta: Prenada Media Group.

Sugiyono. 2015. Metode Penelitian Bisnis. Bandung: Alfabeta.

Umar, H. 2015. Sumber Daya Manusia Dalam Organisasi, Jakarta: PT. Gramedia Pustaka Utama.

Wibowo, 2015, Manajemen Kinerja, Edisi ketiga. Jakarta: PT Raja Grafindo Persada

Wijaya, G. 2015. Penerapan Manajemen Kinerja Klinik Berbasis Tri Hita
Karana Pada Kepuasan Kerja, Komitmen Kerja Dan Locus of Control Terhadap Peningkatan Kinerja karyawan Di Unit Rawat Inap Rumah Sakit Umum Bangli. Disertasi: UNUD.

Wirawan. 2017. Evaluasi Kinerja Sumber Daya Manusia: Teori Aplikasi dan Penelitian. Jakarta: Salemba Empat

Wisudaningsi, B. A., I. Arofah dan K. A. Belang. 2019. Pengaruh Kualitas Pelayanan dan Kualitas Produk Terhadap Kepuasan Konsumen dengan Menggunakan Metode Analisis Regresi Linear Berganda. Jurnal Statistika dan Matematika. 1(1): 103-116. 